\title{
EFEKTIFITAS MODEL PEMBELAJARAN KOOPERATIF TIPE STAD DAN NHT BERBANTUAN ALAT PERAGA SISTEM PERNAPASAN MANUSIA TERHADAP MOTIVASI DAN HASIL BELAJAR KOGNITIF SISWA
}

\section{Effectiveness Model Type of Cooperative Learning Stad and Equipment Assisted NHT Respiratory System of Human Figure to Student's Cognitive Motivation and Learning Outcomes}

\author{
Nonci Melinda Uki \\ Program Studi Pendidikan Biologi, Sekolah Tunggi Keguruan dan Ilmu \\ Pendidikan, STKIP SoE, Nusa Tenggara Timur, Indonesia. \\ email: noncimelindauki@gmail.com
}

\begin{abstract}
This study aims to the effectiveness of cooperative learning model type STAD, NHT and Conventional aided props to the motivation and learning outcomes of students on the material the respiratory system in humans. The method used Quasi-Experiment with design Nonequivalent control group design involving three classes, which use the model of STAD, NHT and Conventional. Data were collected through test result of learning and motivation questionnaire were analyzed descriptively (Anova) at $\alpha=$ 0.05 . The results showed that the learning outcomes STAD group (36.47), NHT group (41.20) and Conventional (34.84). It can be concluded that there are differences between the models STAD learning outcomes, NHT and Conventional on the subject of the respiratory system in humans. This shows that the use of cooperative learning model NHT more effective in improving student learning outcomes compared with STAD and conventional models. The third model applied learning effectively increase student motivation.
\end{abstract}

Keywords : Learning Outcomes, Motivation, NHT, STAD, Viewer Tool. 
Uki, N. M.

\section{PENDAHULUAN}

Hasil observasi di beberapa sekolah di Kabupaten Timor Tengah Selatan (TTS) menunjukkan bahwa hasil belajar yang diperoleh siswa masih di bawah kriteria ketuntasan minimum (KKM). Hal ini disebabkan karena sarana prasarana dalam proses pembelajaran yang kurang memadai, keterbatasan kreativitas guru dalam memilih metode yang tepat dalam proses pembelajaran, keterbatasan guru dalam mengembangkan berbagai strategi pembelajaran yang menarik siswa untuk belajar, dan masih banyak guru yang belum memanfaatkan media pembelajaran sehingga siswa merasa bosan dan pada akhirnya berpengaruh pada motivasi dan hasil belajar siswa. Oleh Karena itu, guru diharapkan untuk menggunakan model pembelajaran yang bervariasi serta menggunakan alat peraga dalam proses pembelajaran sehingga dapat membangkitkan motivasi siswa untuk belajar secara mandiri dan bekerja sama dengan peserta didik yang lain.

Materi sistem pernapasan pada manusia merupakan materi yang bersifat abstrak dan berkaitan dengan mekanisme serta proses yang terjadi di dalam tubuh, sehingga sulit bagi siswa untuk memahami materi tersebut. Oleh karena itu, untuk membantu siswa dalam memahami materi sistem pernapasan pada manusia maka dalam proses pembelajarannya diperlukan bantuan alat peraga. Alat peraga dapat menjelaskan/menunjukkan/membuktikan konsep-konsep atau gejala-gejala yang dipelajari. Pemanfaatan alat peraga diharapkan mampu mengurangi kesulitan yang dialami siswa dan membantu guru dalam pembelajaran sehingga penyampaian konsep lebih bermakna dan dapat meningkatkan pemahaman siswa terhadap konsep yang dipelajarinya, dengan demikian akan tercipta suatu proses pembelajaran yang berkualitas.

Hasil observasi di SMA Efata SoE dalam pembelajaran biologi terutama materi sistem pernapasan pada manusia, ternyata proses pembelajarannya berpusat pada buku paket yang sudah ada, belum memanfaatkan media pembelajaran berupa alat peraga dan kurang memberikan kesempatan kepada siswa untuk beraktivitas dalam proses pembelajaran sehingga motivasi dan hasil belajar siswa rendah. 
Dengan perkembangan ilmu pengetahuan dan teknologi, maka perlu adanya perubahan pendekatan pembelajaran yang semula teacher centered menjadi student centered. Pembelajaran secara klasikal yang berubah menjadi pembelajaran kooperatif, bertujuan untuk memaksimalkan kerja sama antar siswa dengan latar belakang dan kemampuan yang heterogen dalam kelompokkelompok kecil. Oleh karena itu, guru diharapkan mengurangi dominasi di dalam kelas, siswa harus aktif berpartisipasi menemukan dan membentuk sendiri pengetahuannya. Ada berbagai model pembelajaran kooperatif, di antaranya adalah model pembelajaran kooperatit tipe STAD (Student Team Achievement Division) dan pembelajaan kooperatif tipe NHT (Numbered Head Together).

Berdasarkan hasil penelitian Balfakih

(2013) menyimpulkan bahwa hasil belajar siswa yang menggunakan model kooperatif tipe STAD lebih baik dari pada dengan model konvensional. Hasil belajar siswa yang menggunakan model kooperatif tipe NHT lebih baik dari pada dengan model konvensional (Jamalong 2012). Sehingga dapat disimpulkan bahwa pembelajaran dengan menggunakan model kooperatif tipe STAD dan NHT memberikan hasil belajar yang lebih baik dari pada dengan model konvensional (Sunandar 2008). Berdasarkan uraian tersebut perlu dilakukan penelitian tentang keefektifan model pembelajaran kooperatif tipe STAD dan NHT berbantuan alat peraga sistem pernapasan manusia di SMA Efata Soe Kabupaten TTS.

Berdasarkan uraian di atas maka tujuan dari penelitian ini adalah menganalisis efektifitas model pembelajaran kooperatif tipe STAD, NHT dan Konvensional berbantuan alat peraga terhadap motivasi dan hasil belajar siswa.

\section{METODE PENELITIAN}

Penelitian ini merupaka penelitian Quasi Experiment dengan desain penelitian yang digunakan adalah Nonequivalent Control Group Design, Sugiyono (2012). Populasi dalam penelitian ini adalah seluruh siswa kelas X1 SMA Efata SoE yang terdiri dari empat kelas yang berjumlah 90 siswa. Pengambilan sampel dalam 
Uki, N. M.

penelitian ini menggunakan Cluster random sampling diambil 3 kelas yang berjumlah 60 siswa, untuk menentukan kelas kontrol dan kelas eksperimen. Kelas IPA ${ }_{1}$ mendapatkan perlakuan dengan model pembelajaran kooperatif tipe STAD, kelas $\mathrm{IPA}_{2}$ mendapatkan perlakuan dengan model pembelajaran kooperatif tipe NHT sedangkan kelas $\mathrm{IPA}_{3}$ dengan pembelajaran konvensional. Data dikumpulkan melalui tes hasil belajar dan angket motivasi yang dianalisis secara deskriptif (Regresi)

\section{HASIL DAN PEMBAHASAN}

Hasil belajar kognitif siswa sebelum dan setelah perlakuan dengan kooperatif tipe STAD, NHT dan Konvensional dapat dilihat pada tabel 1.

Tabel 1.

Rata-rata Nilai Pretest dan Postest dari Kelas STAD, NHT dan Konvensional

\begin{tabular}{|c|c|c|c|c|c|c|}
\hline & \multicolumn{6}{|c|}{ Perlakuan } \\
\hline & \multicolumn{2}{|c|}{ STAD } & \multicolumn{2}{|c|}{ NHT } & \multicolumn{2}{|c|}{ Konvensional } \\
\hline & Pretest & Postest & Pretest & Postest & Pretest & Postest \\
\hline $\begin{array}{l}\text { Jumlah } \\
\text { siswa }\end{array}$ & 30 & 30 & 30 & 30 & 30 & 30 \\
\hline $\begin{array}{l}\text { Rata- } \\
\text { rata }\end{array}$ & 40.17 & 76.57 & 41.93 & 82.80 & 39.83 & 73.27 \\
\hline
\end{tabular}

Tabel 1 berdasarkan hasil analisis regresi menunjukkan bahwa skor rata-rata sebelum perlakuan (Pretest) lebih rendah dibandingkan rata-rata setelah perlakuan (Postesst) Perbedaan hasil belajar kognitif siswa ketiga kelas, dilakukan uji statistik antara selisih nilai Post-test dan Pre-test dapat dilihat pada tabel 2. 


\section{Tabel 2}

Rata-rata Hasil Belajar Kognitif Siswa Antara Selisih Nilai PosttestPretest pada Kelas STAD, NHT dan Konvensional

\begin{tabular}{ccc}
\hline $\begin{array}{c}\text { Model } \\
\text { Pembelajaran }\end{array}$ & $\begin{array}{c}\text { Jumlah } \\
\text { siswa }\end{array}$ & Rata-rata \\
\hline NHT & 30 & $41,20^{\mathrm{a}}$ \\
STAD & 30 & $36,47^{\mathrm{b}}$ \\
Konvensional & 30 & $34,84^{\mathrm{c}}$ \\
\hline
\end{tabular}

Keterangan:

Huruf yang berbeda dalam kolom yang sama menunjukkan ada berbeda nyata menurut uji Tukey pada taraf signifikansi $\alpha=0,05$.

Peningkatan hasil belajar siswa terlihat pada Tabel 2 menunjukan bahwa rata-rata peningkatan hasil belajar kognitif siswa yang diajar dengan metode NHT memiliki peningkatan yang lebih efektif dibandingkan dengan kelas STAD dan Konvensional. Hal ini dimungkinkan karena pada kelas NHT dengan penomoran menjadikan siswa lebih aktif dan bertanggungjawab dengan segala aktivitasnya. Pengajaran kooperatif lebih menekankan pembelajaran yang berpusat pada siswa (student centered learning) disertai unsur-unsur penanaman sikap siswa antara lain, jujur, peduli, disiplin, tanggung jawab, berani, menghargai, aktif, percaya diri, dan kerjasama dalam kelompok. Campbell (2013), menyatakan nilai-nilai moral atau sikap siswa harus benar-benar menyatu dan diterapkan dalam keseharian siswa dan juga didalam kelas. Sikap, aktif, berani dan tanggung jawab siswa pada kegiatan diskusi presentasi terlihat dengan banyak siswa yang terlibat aktif bertanya, menjawab pertanyaan maupun memberikan tanggapan terkait materi sistem pernapasan pada manusia. Hal ini didukung pernyataan Rustaman (2005) yang menyatakan bahwa pembelajaran aktif dan menarik dapat merangsang tumbuhnya sikap ilmiah, jujur, kerja sama dan bertanggung jawab.

Peningkatan hasil belajar kognitif juga tidak terlepas dari penggunaan media pengajaran berupa alat peraga sederhana pada materi sistem pernapasan. Penggunaan alat peraga sederhana, siswa akan lebih muda memahami materi pelajaran. Selain itu siswa akan lebih termotivasi untuk belajar karena pembelajaran 
yang tidak monoton. Hal ini sesuai dengan pendapat Sudjana (2000), bahwa media pengajaran dalam proses belajar menyebabkan pengajaran lebih jelas maknanya sehingga dapat lebih dipahami oleh siswa dan memungkinan siswa menguasai dan mencapai tujuan pengajaran serta membuat pengajaran lebih menarik perhatian siswa sehingga dapat menumbuhkan motivasi belajar siswa. sejalan dengan penelitian yang dilakukan oleh Prasetyarini et al. (2013), hasil penelitian menunjukkan bahwa pemanfaatan alat peraga IPA dapat meningkatkan pemahaman konsep fisika siswa. hal ini ditandai dengan meningkatnya pemahaman konsep fisika siswa pada setiap siklus.

Berdasarkan hasil uji Post Hoc untuk mengetahui kelompok yang berbeda signifikan pada hasil kognitif siswa serta menjawab ketiga hipotesis maka hipotesis yang pertama adalah signifikansi antara model STAD dan NHT diperoleh nilai sig. 0,000<0,05 artinya ada perbedaan yang signifikan antara model STAD dan NHT. Untuk membuktikan perbedaan rata-rata kedua model pembelajaran dilihat dari rata-rata analisis deskriptif model pembelajaran STAD dan NHT adalah 36,47 dan 41,20, sehinga disimpulkan bahwa pada rumusan masalah pertama model pembelajaran kooperatif tipe NHT efektif meningkatkan hasil belajar siswa dibandingkan dengan model STAD. Hal ini didukung penelitian Nugroho (2011), menyimpulkan bahwa pembelajaran kimia dengan menggunakan model pembelajaran kooperatif tipe NHT lebih efektif dari pada pembelajaran kimia dengan menggunakan model pembelajaran kooperatif tipe STAD pada konsep laju reaksi.

Hipotesis yang kedua adalah signifikansi antara model pembelajaran STAD dengan Konvensional diperoleh nilai sig. 0,037 $<0,05$ artinya ada perbedaan yang signifikan antara model STAD dengan Konvensional. Untuk membuktikan perbedaan rata-rata kedua model pembelajaran dapat dilihat dari rata-rata analisis deskriptif kedua model pembelajaran STAD dengan Konvensional adalah 36,47 dan 34,84 sehingga disimpulkan bahwa pada rumusan masalah kedua model pembelajaran STAD efektif meningkatkan hasil belajar kognitif siswa dibandingkan konvensional. Hal ini didukung oleh penelitian Aziz et al. (2006), yang menyimpulkan bahwa penerapan model pembelajaran 
kooperatif dengan memanfaatkan alat peraga sederhana dapat meningkatkan hasil belajar siswa, baik secara kognitif, afektif maupun psikomotorik, serta kemampan kerja sama siswa. sejalan dengan penelitian yang dilakukan oleh Lailiya et al. (2013), yang menunjukkan bahwa ketuntasan klasikal siswa meningkat seiring dengan meningkatnya kemampuan guru mengelola model pembelajaran kooperatif tipe STAD.

Hipotesis yang ketiga adalah signifikansi antara model NHT dengan Konvensional diperoleh nilai sig. 0,000 $<0,05$ artinya ada perbedaan hasil belajar yang signifikan. Untuk membuktikan perbedaan rata-rata pada kedua model pembelajaran dilihat dari analisis deskriptif statistik kedua model pembelajaran adalah 41,20 dan 34,84 sehingga disimpulkan bahwa pada rumusan ketiga model pembelajaran NHT efektif meningkatkan hasil belajar kognitif siswa dibandingkan Konvensional. Hal ini didukung oleh penelitian Siregar (2012) yang mengatakan bahwa pengaruh yang signifikan menggunakan model pembelajaran kooperatif tipe NHT terhadap hasil belajar siswa. sejalan dengan penelitian Muis et al (2011) menyimpulkan bahwa model pembelajaran kooperatif tipe NHT dapat meningkatkan hasil belajar siswa. Analisis data motivasi belajar siswa dapat diliht pada tabel 3.

\section{Tabel 3}

Analisis Data Deskriptif Motivasi Belajar Siswa

\begin{tabular}{|c|c|c|c|}
\hline \multicolumn{4}{|c|}{ Deskriptif } \\
\hline Model & Jumlah & Rata-rata & Std. \\
\hline Pembelajaran & Siswa & Total Skor & Devision \\
\hline STAD & 30 & $50.20^{a}$ & 6.025 \\
\hline NHT & 30 & $52.07^{a}$ & 4.226 \\
\hline Konvensional & 30 & $50.11^{\mathrm{a}}$ & 5.191 \\
\hline
\end{tabular}

Keterangan:

Huruf yang sama dalam kolom menunjukkan tidak berbeda nyata pada taraf signifikansi $\alpha=0,05$. Data dapat disimpulkan bahwa motivasi siswa ketiga model pembelajaran tidak berbeda nyata. 
Uki, N. M.

Hasil uji regresi menunjukkan bahwa Motivasi belajar siswa pada ketiga perlakuan tidak berbeda nyata (Tabel 2). Hal ini dimungkinkan karena ketiga kelas perlakuan baik itu kelas STAD, NHT dan Konvensional, ternyata siswa memiliki motivasi yang tinggi untuk belajar namun tidak dapat meningkatkan hasil belajar kognitif. Hal ini dibuktikan dengan pengisian angket oleh siswa, setelah dianalisis ternyata siswa tertarik untuk belajar, mengerjakan tugas, dan selalu menjawab pertanyaan yang diajukan oleh guru, sehingga rata-rata siswa memiliki motivasi yang tinggi untuk belajar. Tercapainya hasil belajar siswa dipengaruhi oleh model pembelajaran yang digunakan dalam kelas.

Penelitian ini menunjukan bahwa, hasil belajar siswa yang diberikan perlakuan NHT lebih efektif dibandingkan dengan kelompok STAD dan Konvensional terlihat dari nilai kognitif siswa selama penelitian menunjukkan peningkatan yang baik terjadi pada kelas NHT. Sementara motivasi belajar siswa dari ketiga model pembelajaran tidak berbeda secara signifikan, artinya ketiga model pembelajaran dapat meningkatkan motivasi siswa.

\section{KESIMPULAN}

Berdasarkan hasil penelitian maka disimpulkan bahwa model pembelajaran kooperatif tipe NHT paling efektif dari pada model STAD dan Kovensional. Ketiga model pembelajaran tidak berpengaruh terhadap motivasi belajar siswa.

\section{DAFTAR PUSTAKA}

Aziz A., Yulianti D., \& Handayani L. 2006. Penerapan Model Pembelajaran Kooperatif dengan Memanfaatkan Alat Peraga sains Fisika (Materi Tata surya) untuk Meningkatkan Hasil Belajar dan Kerja Sama Siswa. Jurnal Pend. Fisika Indonesia, Vol. 4, No. 2.

Balfakih, M. A. N. 2003. The effectiveness of student team achievement division (STAD) for teaching high school chemistry in the United Arab Emirates. Journal of Chemistry Education 2 (3): 605-624. 
Campbell, E. 2003. The Ethical Teacher. New York: Open University Press.

Jamalong, A. 2012. Meningkatkan Hasil Belajar Siswa melalui Model Kooperatif Numbered Heads Together (NHT) di Kelas X SMA Negeri 1 Beduai Kabupaten Sanggau. Jurnal Pendidikan dan Kebudayaan, 18 (4).

Lailiya., Rochmatul., Muliatna., \& I Made. 2013. Penerapan MPK Tipe STAD (Students Tiem Achievement Divisions) untuk meningkatkan hasil belajar siswa XI TKR SMKN 3 Buduruan-Sidoarjo. Jurnal Pendidikan Teknik Mesin, (Online), 01 (02), (http://ejournal.unesa.ac.id).

Muiz A., Aminudin PP., \& Naparin A. 2011. Meningkatkan Proses dan Hasil Belajar Siswa Kelas XI IPA 1 SMA Negeri 11 Banjarmasin pada Konsep Sistem Gerak dengan Menggunakan Pembelajaran Kooperatif tipe Number Head Together. Jurnal Wahana-Bio, Vol.V

Nugroho E. A. 2011. Perbedaan Hasil Belajar Siswa Anntara Model Pembelajaran NHT (Numbered Head Together) dengan STAD (Student Team Achievment) pada Konsep Laju Reaksi. Skripsi. Jakarta: FITK: UIN

Prasetyarini, A., Siska, D.F., \& Wakhid, R.A. 2013. Pemanfaatan Alat Peraga IPA untuk Meningkatkan Pemahaman Konsep Fisika pada Siswa SMP Negeri 1 Bulus Pesantren Kebumen. Jurnal Radiasi. 2 (1).

Rustaman, N. (2005). Perkembangan Penelitian Pembelajaran Berbasis Inkuiri dalam Pendidikan Sains. Makalah Seminar Nasional II Himpunan Ikatan Sarjana dan Pemerhati IPA Indonesia. FPMIPIPA UPI. 
Uki, N. M.

Siregar, F.A. 2012. Pengaruh model kooperatif tipe NHT terhadap hasil belajar siswa kelas VIII SMP Negeri Medan. Jurnal Pendidikan Fisika. 1 (1): 2252-732x.

Sudjana N. 2000. CBSA. Dasar-dasar Proses Mengajar. Bandung: PT Sinar Baru Algeandra.

Sugiyono. 2012. Metode Penelitian Pendidikan Pendekatan Kuantitatif, Kualitatif, dan $R$ \& D. Bandung: Alfabeta.

Sunandar. 2008. Pengaruh Model Pembelajaran terhadap Minat dan Hasil Belajar Matematika Siswa Kelas V SDN. Jurnal Varia Pendidikan. 20 (2). 